\title{
Effect of Nitrogen Fertilization Rates, Plant Spacing and Their Interaction on Essential Oil Percentage and Total Flavonoid Content of Summer Savory (Satureja hortensis L.) Plant
}

\author{
A.S. EL-Leithy ${ }^{1}$, S.H. EL-Hanafy ${ }^{1}$, M. E. Khattab ${ }^{2}$, S.S. Ahmed ${ }^{2}$ and A.A.A. EL- \\ Sayed $^{2 *}$ \\ ${ }^{1}$ Ornamental Horticulture Department, Faculty of Agriculture, Cairo University, and \\ ${ }^{2}$ Medicinal and Aromatic Plants Research Department, National Research Centre, \\ Dokki, Giza, Egypt.
}

\begin{abstract}
UMMER savory (Satureja hortensis L.) plant is one of the most promising plants suitable for cultivation in the conditions of Egypt. A field experiment was carried out at Department of Ornamental Horticulture, Faculty of Agriculture, Cairo University, with Department of Medicinal and Aromatic Plants Research, National Research Center, Dokki, Giza, Egypt. during two successive seasons 2014 and 2015. The experimental design was a factorial in split plot with three replicates. The aim of the work was to study the effect of nitrogen fertilization at the rates of $\mathrm{N} 0, \mathrm{~N} 1, \mathrm{~N} 2$ and $\mathrm{N} 3(0,40,80$ and $120 \mathrm{~kg} \mathrm{~N} /$ feddan ) as equivalents $0.0,200$, 400 and $600 \mathrm{~kg}$ /feddan of ammonium sulfate fertilizer $20.5 \% \mathrm{~N}$, respectively as the main plots. Plant spacing was defined as S1, S2 and S3 $(45 \times 50,30 \times 50$ and $15 \times 50 \mathrm{~cm}$, respectively) between the plants, as sub-plots. The effect of these treatments on essential oil percentage, essential oil constituents and total flavonoid content of $S$. hortensis L. was recorded. The results showed that the highest level of $\mathrm{N}$ fertilizer to combined with the least plant spacing had a significant effect on increasing the essential oil percentages in both seasons. The major essential oil constituents were carvacrol (47.26 and 42.90\%) and $\gamma$-terpinene (38.30 and 39.10\%) at the first and second cuts, respectively. Generally, carvacrol content was not affected by $\mathrm{N}$ fertilizer, but the $\gamma$-terpinene content increased slightly. The other lower percentage components arranged in descending order including $\rho$-cymene, terpinolene, $\alpha$-terpinene, $\alpha$-pinene and $\alpha$-thujene contents were not significantly affected by such treatments. Total flavonoid content decreased with all $\mathrm{N}$ fertilizer levels at the first cut (June), the opposite trend was noticed at the second cut (August) in both seasons. Plant spacing at intermediate density was associated with the production of high contents of total flavonoids at both cuts during both seasons.
\end{abstract}

Keywords: Summer savory, Satureja hortensis L., N fertilization, Plant spacing, Carvacrol, $\gamma$-terpinene, Total flavonoids.

\section{Introduction}

Summer savory (Satureja hortensis L.) plant which belongs to Lamiaceae family is an annual herb up to $45 \mathrm{~cm}$ high with slender, erect, slightly hairy stems, linear leaves and small, pale lilac flowers. It is native to Europe, naturalized in North America. It is extensively cultivated in Spain, France, Yugoslavia and the USA and recently in Egypt for the production of essential oil. It is popular culinary herb, with a peppery flavour. It has been used therapeutically mainly as a tea for various ailments including digestive complaints (cramp, nausea, indigestion, intestinal parasites), menstrual disorders and respiratory conditions (asthma, catarrh, sore throat). Applied externally, the fresh leaves bring instant relief from insect bites, bee and wasp stings [1].

Plant nutrition is one of the most important factors that increase plant production. Nitrogen has the most recognized role in plant nutrition as it is in corporate in the structure of the protein molecule. Nitrogen is found in such important

*Corresponding author e-mail: ahmedawad_888@yahoo.com 
molecules as purines, pyrimidines, porphyrines and coenzymes. purines and pyrimidines are found in the nucleic acids RNA and DNA essential for protein synthesis. Accordingly, nitrogen plays an important role in synthesis of the plant constituents through the action of different enzymes [2-5].

Plant spacing is an important factor in determining the microenvironment for the Satureja hortensis L. and other medicinal and aromatic plants. The optimization of this factor can lead to a higher essential oil yield and a better chemical composition [6-10].

Essential oil of summer savory (Satureja hortensis L.) was extracted by hydro distillation from the whole fresh and dried herb. An oleoresin is also produced by solvent extraction. The principal constituents are carvacrol, $\gamma$-terpinene,pinene, cymene, camphene, limonene, phellandrene and borneol. This essential oil and oleoresin are used in perfumery work and in most major food categories especially meat products and canned food $[1,11,12]$.

Total flavonoids are the largest group of phytonutrients, with more than 6.000 types. Some of the best - known flavonoids are quercetin and kaempferol. Flavonoids are powerful antioxidant with anti-inflammatory and immune system benefits. Diets rich in flavonoid containing foods are sometimes associated with prevention of cancer, neurodegenerative and cardiovascular disease. [13-15].

The objective of this study was to investigate the effect of nitrogen fertilizer, plant spacing and their interaction on the essential oil percentage and constituents as well as total flavonoids of Satureja hortensis L. plant in loamy soil conditions.

\section{Materials and Methods}

This study was carried out at the Department of Ornamental Horticulture, Faculty of Agriculture, Cairo University. The experiments investigations were carried out at Department of Medicinal and Aromatic Plants Research, National Research Center Dokki, Giza, Egypt, in the two successive seasons of 2014 and 2015.

The seeds of summer savory (Satureja hortensis L.) were imported from Jellitto Staudensamen GmbH, Schwarmstedt, Germany by Sekem Company, Egypt. The seeds were sown on $15^{\text {th }}$ February 2014 and 2015 (in the two seasons) at the seeds were sown directly into a "nursery" seed bed inside green house in peat moss medium. After 45 days from sowing the seeds on $1^{\text {st }}$ April 2014 and 2015, when the seedlings were $12-15 \mathrm{~cm}$. height, they were transplanted to prepared plots in the experimental field.

The soil was prepared on $15^{\text {th }}$ March 2014 for the first season and $20^{\text {th }}$ March 2015 for the second season: Compost $5 \mathrm{~m}^{3} / \mathrm{fed}$ and super-phosphate $15.50 \% \mathrm{P}_{2} \mathrm{O}_{5}(200 \mathrm{~kg} / \mathrm{fed})$ were added during soil preparation, while Potassium sulfate $\left(48 \% \mathrm{~K}_{2} \mathrm{O}\right)$ as a mineral fertilizer $(100 \mathrm{~kg} / \mathrm{fed})$ was added in two doses, the first dose added during the soil preparation, while the second one was added two weeks after the first cut.

The experiment included 12 treatments, in three replicates, each was comprised of randomly distributed plots. The experiment was designed as split plots, with the main plots were assigned to different nitrogen levels (N0, N1, N2 and N3 as $0 \mathrm{~N}, 40 \mathrm{~N}, 80 \mathrm{~N}$ and $120 \mathrm{~N} \mathrm{~kg}$ /feddan, respectively), while subplots were assigned to plant spacing $\mathrm{S} 1, \mathrm{~S} 2$ and $\mathrm{S} 3(45,30$ and $15 \mathrm{~cm}$, respectively) between the plants .Each experimental unit (plot) which was $2 \times 1.6 \mathrm{~m}\left(3.2 \mathrm{~m}^{2}\right)$ divided into 4 rows with $50 \mathrm{~cm}$ apart and 45, 30 and $15 \mathrm{~cm}$ between the plants, i.e. the plots contained 16, 24 and 36 plants, respectively. Then, the treatments replicated three times (36 plots).

Nitrogen fertilizer at different levels $0,40,80$ and $120 \mathrm{~kg} \mathrm{~N}$ equivalents $0.0,200,400$ and 600 $\mathrm{kg} /$ feddan as Ammonium sulphate $(20.5 \% \mathrm{~N})$ in two doses, the first dose was added 21 days after transplanting, while the second one was added after the first cut during both seasons.

\section{Recorded data:}

Summer savory (Satureja hortensis L.) plant were harvested two times at the early bloom stage on $2^{\text {nd }}$ June and $5^{\text {th }}$ August 2014 for the first and the second cuts, respectively, in the first season and on 10th June and $13^{\text {th }}$ August 2015 for the first and the second cuts, respectively, in the second season. The plants were harvested by cutting vegetative parts at $10 \mathrm{~cm}$ above the soil surface.

Data were recorded in the two seasons as the following:

1.Essential oil percentage in fresh herb. 
2.Essential oil components by GC (Gas Chromatography).

3.Total of flavonoids mg / g. Dry Weight.

\section{Essential oil percentage in the fresh herb}

The oil percentage was determined in fresh herb in both seasons using the hydro-distillation method by Clevenger apparatus according to Guenther[16]. A known weight of fresh herb (100 g) was placed in a flask of 1 L capacity for distillation, and an adequate amount of water was added. A proper essential oil trap and condenser were attached to the flask and enough water was added to fill the trap. The distillation continued for 3.0 hours until no further increase in the oil was observed. After finishing the distillation process the apparatus was left to be cooled. The volume of the extracted essential oil was determined and recorded.

The obtained oil samples were then dehydrated over anhydrous sodium sulfate and stored in glass vials with Teflon-sealed at $2{ }^{\circ} \mathrm{C}$ in the absence of light for oil analysis the essential oil percentage was estimated as follows:

$$
\text { Essential oil \% }=\frac{\text { Essential oil vol. (Measuring pipette reading) }}{\text { Weight of sample }} \times 100
$$

\section{Essential oil components}

Samples taken from the essential oil obtained in the first season were analyzed using GC analysis, to determine their main constituents. The use of GC in the quantitative determinations was performed using the methods described by Tatjana [17].

The GC analysis of the essential oil samples was carried out in the first season using gas chromatography instrument stands at the Laboratory of Medicinal and Aromatic Plants, National Research Center with the following specifications.

Instrument: Instrument capillary GC-2010 plus Gas Chromatographs (Shimadzu Corp., Japan), coupled with a Shimadzu FID 2010 Plus detector (Flame Ionization Detector). The GC system was equipped with a Stabilwax column (30 m x $0.25 \mathrm{~mm}$ i.d., $0.25 \mu \mathrm{m}$ film thickness). Analyses were carried out using helium as carrier gas at a flow rate of $1.0 \mathrm{~mL} / \mathrm{min}$ at a split ratio of $1: 10$ and the following temperature program: $40^{\circ} \mathrm{C}$ for $1 \mathrm{~min}$; rising at $4.0^{\circ} \mathrm{C} / \mathrm{min}$ to $150^{\circ} \mathrm{C}$ and held for $6 \mathrm{~min}$; rising at $4^{\circ} \mathrm{C} / \mathrm{min}$ to $210^{\circ} \mathrm{C}$ and held for $1 \mathrm{~min}$. The injector and detector were held at $210^{\circ}$ and $250^{\circ} \mathrm{C}$, respectively. Diluted samples $(1: 10$ hexane, $\mathrm{v} / \mathrm{v})$ of $0.2 \mu \mathrm{L}$ of the mixtures were always injected. Most of the compounds were identified using GC standards (Sigma Aldrich GC standards). The obtained chromatogram and analysis report for each sample were analyzed to calculate the percentage of the main volatile oil components. The area of each peak was first calculated by an automatic integrator. The areas were then summed, and the total area of the peaks represented the whole sample. The percentage of each component was the ratio between its peak area to the total peak areas, multiplied by 100 .

\section{Total flavonoid content Quercetin equivalent / $g$ Dry Weight.}

\section{Extraction of plant materials}

One gram of each dry sample was extracted with $25 \mathrm{ml}$ of methanol using an Ultrasonic bath Bandelin Sonorex (Germany) at $35 \mathrm{kHz}$ and 200 $\mathrm{W}$ for $60 \mathrm{~min}$ at room temperature. The extracted samples were filtered through Whatman filter paper No. 4 and the filtrate was evaporated to dryness under vacuum and the yield of the extract from each sample was calculated. Each extract was dissolved in $10 \mathrm{ml}$ methanol, $0.1 \mathrm{ml}$ of sample solution, $1.5 \mathrm{ml}$ of methanol, $2.8 \mathrm{ml}$ of water, $0.1 \mathrm{ml}$ of potassium acetate $(1 \mathrm{M})$ and $0.1 \mathrm{ml} 2 \%$ $\mathrm{AlCl} 3$ solution dissolved in methanol were added and mixed. After incubation at room temperature for $30 \mathrm{~min}$, the absorbance was determined using spectrophotometer at $\lambda \max =415 \mathrm{~nm}$., the concentration of flavonoids was read $(\mathrm{mg} / \mathrm{ml})$ on the calibration line; then, the content of flavonoids in extracts was expressed in terms of Quercetin equivalent (mg of Quercetin /g of extract).was expressed as milligrams of Quercetin equivalent per $100 \mathrm{~g}$ of dried plant (mg Quercetin/100 g) [18].

\section{Statistical analysis of data:}

Data recorded on essential oil percentage was statistically analyzed, and separation of means was performed using the Least Significant Difference (L.S.D.) test at the 5\% level [19].

\section{Results and Discussion}

I. Effect of nitrogen fertilization rates, plant spacing and their interaction on essential oil percentage of Summer savory (Satureja hortensis L.) plant.

Table 1 shows the effect of different

Egypt.J.Chem. 60, No.5 (2017) 
concentrations of nitrogen fertilizer on the essential oil percentage of summer savory in the first season. Data indicated that increasing the nitrogen fertilizer application rate caused gradual steady increases significantly the essential oil percentage at the first and second cuts in the first season. The favorable effect of nitrogen fertilizer on essential oil percentage was particularly evident at the 80 and $120 \mathrm{~kg} \mathrm{~N} /$ feddan, which gave significantly higher essential oil percentages with mean values 0.596 and $0.612 \%$ in the first cut and 1.017 and $1.129 \%$ in the second cut, respectively than any other $\mathrm{N}$ fertilization treatments.

TABLE 1. Effect of nitrogen fertilization, plant spacing and their interaction on essential oil percentage of Satureja hortensis L. plant in the first season, 2014.

\begin{tabular}{|c|c|c|c|c|c|}
\hline \multirow{2}{*}{ Plant spacing (S) } & \multicolumn{4}{|c|}{ Nitrogen fertilization (N) } & \multirow{2}{*}{ Mean } \\
\hline & No & N1 & $\mathbf{N 2}$ & N3 & \\
\hline \multicolumn{6}{|c|}{ First cut } \\
\hline S1 & 0.540 & 0.543 & 0.550 & 0.553 & 0.547 \\
\hline S2 & 0.583 & 0.590 & 0.593 & 0.583 & 0.588 \\
\hline S3 & 0.607 & 0.597 & 0.643 & 0.700 & 0.637 \\
\hline Mean & 0.577 & 0.577 & 0.596 & 0.612 & 0.590 \\
\hline \multicolumn{3}{|l|}{ L.S.D at 0.05 for $N$} & 0.031 & & \\
\hline & & & 0.036 & & \\
\hline \multirow[t]{2}{*}{$\mathbf{N} \times \mathbf{S}$} & & & 0.054 & & \\
\hline & & econd $\mathrm{c}$ & & & \\
\hline S1 & 0.800 & 0.873 & 0.950 & 1.013 & 0.909 \\
\hline S2 & 0.803 & 0.950 & 0.973 & 1.203 & 0.983 \\
\hline S3 & 0.837 & 1.127 & 1.127 & 1.170 & 1.065 \\
\hline Mean & 0.813 & 0.983 & 1.017 & 1.129 & 0.986 \\
\hline L.S.D at 0.05 for $N$ & & & 0.044 & & \\
\hline $\mathbf{S}$ & & & 0.011 & & \\
\hline \multicolumn{3}{|l|}{$\mathbf{N} \times \widetilde{\mathbf{S}}$} & 0.077 & & \\
\hline \multicolumn{6}{|c|}{$\begin{array}{l}\text { N. fertilization: } \mathrm{N} 0=0.0, \mathrm{~N} 1=40, \mathrm{~N} 2=80 \text { and } \mathrm{N} 3=120 \mathrm{Kg} \mathrm{N} / \text { feddan } \\
\text { Plant spacing: } \mathrm{S} 1=45 \mathrm{~cm}, \mathrm{~S} 2=30 \mathrm{~cm} \text { and } \mathrm{S} 3=15 \mathrm{~cm}\end{array}$} \\
\hline
\end{tabular}

Data presented in the second season in Table 2 indicated that increasing the nitrogen fertilizer levels (from 0 to $120 \mathrm{~kg} \mathrm{~N} /$ feddan) caused gradual increases with insignificant different between $\mathrm{N}$ treatments in the first cut. Whereas in the second cut the essential oil percentages of summer savory plant were gradual steady increased significantly, i.e. all nitrogen fertilizer levels (N1, N2 and N3) significantly increased the essential oil percentage with mean values $0.946,0.948$ and $0.992 \%$, respectively compared with $0.858 \%$ for untreated plants (without nitrogen fertilizer). Similar results were recorded in both cuts of the first season Many investigators agreed with these results $[11,5,3]$.

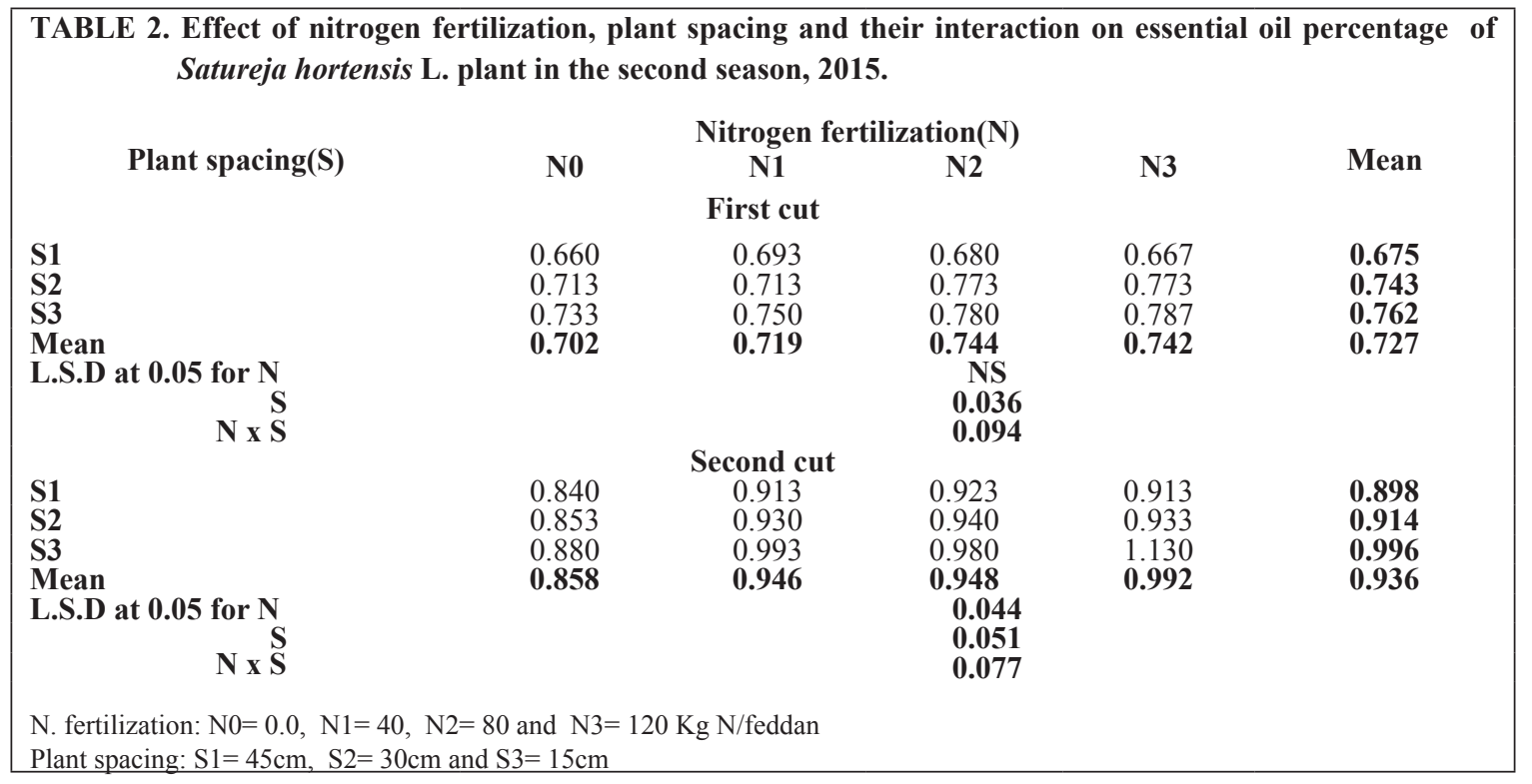

Egypt.J.Chem. 60, No.5 (2017) 
Values for essential oil percentage in the fresh herb of summer savory (Satureja hortensis L.) plants during the two seasons (Tables 1 and 2) show variation in different plant spacing in both seasons. The narrowest spacing S3 $(15 \times 50 \mathrm{~cm})$ gave the highest significant volatile oil percentage in comparison with the medium S2 $(30 \times 50 \mathrm{~cm})$ and widest $\mathrm{S} 1(45 \times 50 \mathrm{~cm})$ spacing at the two cuts in both seasons, which recorded $0.637,0.588$ and $0.547 \%$ in the first cut, and $1.065,0.983$ and $0.909 \%$ in the second cut during the first season for narrowest, medium and widest spacing, respectively Also, the mean values showed the same trend at the first and second cuts of the second season.

Concerning the interaction treatments, there was a significant effect on the oil percentage of summer savory plant at both cuts in both seasons. During both seasons, the highest mean values of essential oil percentage were obtained as a result of the combination treatment between the highest level of nitrogen fertilizer $(120 \mathrm{Kg} / \mathrm{Fed}$.) with the widest spacing (45 $\mathrm{cm} \times 50)$ which recorded 0.700 and $1.170 \%$ for the first season as well as 0.787 and $1.130 \%$ for the second season during $1^{\text {st }}$ and $2^{\text {nd }}$ cuts, respectively. On the other hand, the combination between unfertilized plants with the narrowest spacing $(15 \times 50 \mathrm{~cm})$ gave the lowest values of essential oil percentage where the values were 0.540 and $0.800 \%$ at the two cuts in the first season and 0.660 and $0.840 \%$ at both cuts in the second seasons, respectively.

In general, data in Tables 1 and 2 show that the essential oil percentage in all treatments in the first cut (June cut) were lower than those in the second one (August cut) in both seasons. Also, the general means of the essential oil percentages were 0.590 and $0.727 \%$ in the first cut and 0.986 and $0.936 \%$ in the second cut in the first and second seasons, respectively, this effect presumably due to longer light duration, higher temperature and higher light intensity previously dominated during summer growing season. This would have been the most suitable condition for oil synthesis and accumulation in the leaves [20-23].

II. Effect of nitrogen fertilization rates, plant spacing and their interaction with essential oil constituents by $G C$

Data presented in Tables 3 and 4 and illustrated in Fig. 1 show the main constituents of the essential oil of summer savory, Satureja hortensis
L. of all treatments at both cuts in the first season as identified by GC. Seven components had been identified in the essential oil. The mean of major components were carvacrol (47.26 and $42.90 \%$ ) and $\gamma$ - terpinene $(38.30$ and $39.10 \%)$ in the first and second cuts, respectively, followed by five components arranged in descending order were $\rho$-cymene (3.91 and $4.02 \%$ ), terpinolene ( 2.48 and $4.40 \%), \alpha$-terpinene (2.65 and 2.82\%), $\alpha$-pinene (1.57 and $1.86 \%)$ and $\alpha$-thujene ( 0.84 and $1.18 \%)$ in the first and second cuts, respectively. The total identified components in the essential oil $97.01 \%$ and $96.28 \%$ at the first and second cuts, respectively $[11,12,3]$.

\section{Carvacrol content (the first major component) is a phenolic compound}

Recorded data in Tables 3 and 4 and Fig. 1 show the effect of nitrogen fertilizer treatments on the carvacrol content in both cuts in the essential oil extracted from summer savory plants. The highest mean contents 48.51 and $44.34 \%$ were obtained in the oil of plants unfertilized by N0 at both cuts, respectively compared to fertilized plants by different nitrogen levels (N1, N2 and N3) had slightly decreased between them at the first and second cuts when compared to control N0 plants. This effect may be due to carcavrol synthesis and accumulation in essential oil of summer savory plants not need to more nitrogen uptake from the soil medium.

The plants grown at widest spacing S1 $(45 \times 50$ $\mathrm{cm})$ contained the slightly higher carvacrol contents in the oil, which gave 48.80 and $43.43 \%$ in both cuts, respectively compared to other plant spacings medium and narrow $(30 \times 50 \mathrm{~cm}$ and $15 \times 50 \mathrm{~cm})$, the means were $45.83,47.16 \%$ and $41.97,43.31 \%$ at both cuts, respectively.

Regarding the interaction between the effect of nitrogen levels and plant spacing on the carvacrol percentage in the essential oil, data presented in Tables 3 and 4 and Fig. 1 show that the highest carvacrol percentages were recorded in oil extracted from plants fertilized by nitrogen at $\mathrm{N} 1$ and planted at a spacing of S1 $(45 \times 50 \mathrm{~cm})$ in the first cut $(52.50 \%)$ and the plants unfertilized by nitrogen when transplanting at a spacing of S1 $(45 \times 50 \mathrm{~cm})$ in the second cut $(47.04 \%)$.

$\gamma$-terpinene content (the second major component) is a mono-terpenes hydrocarbon compound

$\gamma$-terpinene percentage was the lowest mean 


\begin{tabular}{|c|c|c|c|c|c|}
\hline \multirow[b]{3}{*}{ Plant spacing (S) } & \multicolumn{5}{|c|}{ The components $(\%)$ of the essential oil } \\
\hline & \multicolumn{5}{|c|}{ Nitrogen fertilization $(\mathbf{N})$} \\
\hline & No & N1 & $\mathbf{N} 2$ & $\mathbf{N 3}$ & Mean \\
\hline & \multicolumn{5}{|c|}{$\alpha$-Thujene } \\
\hline S1 & 1.01 & 0.42 & 0.45 & 0.86 & 0.69 \\
\hline S2 & 0.89 & 0.97 & 1.01 & 1.01 & 0.97 \\
\hline S3 & 0.90 & 0.99 & 0.59 & 0.97 & 0.86 \\
\hline \multirow[t]{2}{*}{ Mean } & 0.93 & 0.79 & 0.68 & 0.95 & 0.84 \\
\hline & \multicolumn{5}{|c|}{$\alpha$-Pinene } \\
\hline S1 & 1.78 & 0.82 & 0.85 & 1.66 & 1.28 \\
\hline $\mathbf{S 2}$ & 1.64 & 1.83 & 1.88 & 1.79 & 1.79 \\
\hline S3 & 1.70 & 1.93 & 1.10 & 1.77 & 1.63 \\
\hline \multirow[t]{2}{*}{ Mean } & 1.71 & 1.53 & 1.28 & 1.74 & 1.57 \\
\hline & \multicolumn{5}{|c|}{$\alpha$-Terpinene } \\
\hline S1 & 2.75 & 2.16 & 2.23 & 2.71 & 2.46 \\
\hline S2 & 2.64 & 2.89 & 2.90 & 2.77 & 2.80 \\
\hline S3 & 2.73 & 2.91 & 2.35 & 2.79 & 2.70 \\
\hline \multirow[t]{2}{*}{ Mean } & 2.71 & 2.65 & 2.49 & 2.76 & 2.65 \\
\hline & \multicolumn{5}{|c|}{$\rho$-Cymene } \\
\hline S1 & 3.99 & 3.29 & 3.30 & 4.07 & 3.66 \\
\hline S2 & 3.84 & 4.37 & 4.25 & 4.10 & 4.14 \\
\hline S3 & 3.95 & 4.15 & 3.55 & 4.08 & 3.93 \\
\hline \multirow[t]{2}{*}{ Mean } & 3.93 & 3.94 & 3.70 & 4.08 & 3.91 \\
\hline & \multicolumn{5}{|c|}{$\gamma$-Terpinene } \\
\hline S1 & 36.77 & 35.69 & 38.63 & 39.53 & 37.66 \\
\hline S2 & 35.96 & 41.77 & 39.95 & 38.43 & 39.03 \\
\hline S3 & 37.17 & 40.55 & 36.55 & 38.51 & 38.20 \\
\hline \multirow[t]{2}{*}{ Mean } & 36.63 & 39.34 & 38.38 & 38.82 & 38.30 \\
\hline & \multicolumn{5}{|c|}{ Terpinolene } \\
\hline S1 & 2.48 & 2.31 & 2.52 & 2.59 & 2.48 \\
\hline S2 & 2.50 & 2.38 & 2.18 & 2.47 & 2.38 \\
\hline S3 & 2.28 & 2.97 & 2.49 & 2.63 & 2.59 \\
\hline \multirow[t]{2}{*}{ Mean } & 2.42 & 2.55 & 2.40 & 2.56 & 2.48 \\
\hline & \multicolumn{5}{|c|}{ Carvacrol } \\
\hline S1 & 48.01 & 52.50 & 49.33 & 45.34 & 48.80 \\
\hline S2 & 49.27 & 42.87 & 44.91 & 46.27 & 45.83 \\
\hline S3 & 48.26 & 43.35 & 50.21 & 46.82 & 47.16 \\
\hline Mean & 48.51 & 46.24 & 48.15 & 46.14 & 47.26 \\
\hline \multirow{2}{*}{\multicolumn{5}{|c|}{$\begin{array}{l}\text { Seven components representing }=(\text { identified }) \\
\text { Other components representing }=(\text { unidentified })\end{array}$}} & $97.01 \%$ \\
\hline & & & & & $2.99 \%$ \\
\hline
\end{tabular}

content in the oil obtained from plants unfertilized by (N0) nitrogen, the values were 36.63 and $37.85 \%$ in both cuts, respectively compared to the plants fertilized by different nitrogen levels of N1, $\mathrm{N} 2$ and N3 (40, 80 and $120 \mathrm{~kg} \mathrm{~N} /$ feddan,) recorded the highest values of $\gamma$-terpinene content, the means were $39.34,38.38$ and $38.82 \%$ at the first cut and $39.94,39.88$ and $38.55 \%$ at the second cut, respectively.
The highest mean content of $\gamma$-terpinene was recorded when the plants cultivated at medium spacing (39.03 and $39.17 \%$ ) in both cuts compared to widest and narrowest plant spacing slightly decreases, the values were $37.66,38.20 \%$ and $39.13,38.87 \%$ at both cuts, respectively.

Concerning the interaction effect between nitrogen levels and plant spacing on $\gamma$-terpinene 
percentage in volatile oil of summer savory, data presented in Table (3 and 4) and Fig. (1) reveal that the highest content $(41.77 \%)$ was recorded in the oil of the plants fertilized by N1 $(40 \mathrm{~kg} \mathrm{~N} /$ fed.) and planted at $S 2(30 \times 50 \mathrm{~cm})$ in the first cut. Also, the plants fertilized by $\mathrm{N} 1$ and planted at wide spacing $\mathrm{S} 1(45 \times 50 \mathrm{~cm})$ resulted the highest content of $\gamma$-terpinene $(43.01 \%)$ compared to other interaction treatments in the second cut.
Other components in essential oil $\alpha$-Thujene, $\alpha$-Pinene, $\alpha$-Terpinene, $\rho$-Cymene and Terpinolene contents

Generally, these components mentioned before in the essential oil of summer savory, Satureja hortensis L., the percentage had no detectable trend as affected by different $\mathrm{N}$ levels fertilizer and plant density as well as interaction between them at the first and second cuts in the

TABLE 4. Effect of nitrogen fertilization and plant spacing and their interactions on the essential oil components (\%) of Satureja hortensis L. plant at the second cut in the first season, 2014.

\begin{tabular}{|c|c|c|c|c|c|}
\hline \multirow{3}{*}{ Plant spacing (S) } & \multicolumn{5}{|c|}{ The components $(\%)$ of the essential oil } \\
\hline & \multicolumn{5}{|c|}{ Nitrogen fertilization $(\mathbf{N})$} \\
\hline & No & N1 & $\mathbf{N 2}$ & N3 & Mean \\
\hline & \multicolumn{5}{|c|}{$\alpha$-Thujene } \\
\hline S1 & 0.83 & 0.80 & 1.30 & 1.20 & 1.03 \\
\hline S2 & 1.27 & 1.77 & 1.10 & 1.27 & 1.35 \\
\hline S3 & 1.32 & 1.12 & 1.07 & 1.16 & 1.17 \\
\hline \multirow[t]{2}{*}{ Mean } & 1.14 & 1.23 & 1.16 & 1.21 & 1.18 \\
\hline & \multicolumn{5}{|c|}{$\alpha$-Pinene } \\
\hline S1 & 1.43 & 1.29 & 2.18 & 2.09 & 1.75 \\
\hline S2 & 1.94 & 2.24 & 1.45 & 2.03 & 1.92 \\
\hline S3 & 1.86 & 1.68 & 1.93 & 2.11 & 1.90 \\
\hline \multirow[t]{2}{*}{ Mean } & 1.74 & 1.74 & 1.85 & 2.08 & 1.86 \\
\hline & \multicolumn{5}{|c|}{$\alpha$-Terpinene } \\
\hline S1 & 2.60 & 2.63 & 3.01 & 2.89 & 2.78 \\
\hline S2 & 2.83 & 3.02 & 2.65 & 2.89 & 2.85 \\
\hline S3 & 2.82 & 2.71 & 2.84 & 2.94 & 2.83 \\
\hline \multirow[t]{2}{*}{ Mean } & 2.75 & 2.79 & 2.83 & 2.91 & 2.82 \\
\hline & \multicolumn{5}{|c|}{$\rho$-Cymene } \\
\hline S1 & 3.76 & 3.88 & 4.43 & 3.94 & 4.00 \\
\hline S2 & 3.95 & 3.76 & 3.92 & 4.38 & 4.00 \\
\hline S3 & 4.07 & 3.95 & 4.06 & 4.20 & 4.07 \\
\hline \multirow[t]{2}{*}{ Mean } & 3.93 & 3.86 & 4.14 & 4.17 & 4.02 \\
\hline & \multicolumn{5}{|c|}{$\gamma$-Terpinene } \\
\hline S1 & 36.79 & 43.01 & 42.10 & 34.60 & 39.13 \\
\hline S2 & 37.25 & 37.62 & 39.74 & 42.07 & 39.17 \\
\hline S3 & 39.52 & 39.20 & 37.79 & 38.97 & 38.87 \\
\hline \multirow[t]{2}{*}{ Mean } & 37.85 & 39.94 & 39.88 & 38.55 & 39.10 \\
\hline & \multicolumn{5}{|c|}{ Terpinolene } \\
\hline S1 & 4.15 & 3.97 & 3.83 & 4.28 & 4.10 \\
\hline S2 & 5.22 & 7.76 & 3.21 & 3.66 & 4.96 \\
\hline S3 & 4.93 & 4.02 & 3.97 & 3.68 & 4.15 \\
\hline \multirow[t]{2}{*}{ Mean } & 4.77 & 5.25 & 3.67 & 3.87 & 4.40 \\
\hline & \multicolumn{5}{|c|}{ Carvacrol } \\
\hline S1 & 47.04 & 40.72 & 39.65 & 46.32 & 43.43 \\
\hline S2 & 44.13 & 39.38 & 44.35 & 40.00 & 41.97 \\
\hline S3 & 41.85 & 43.56 & 44.94 & 42.90 & 43.31 \\
\hline Mean & 44.34 & 41.22 & 42.98 & 43.07 & 42.90 \\
\hline \multicolumn{5}{|c|}{ Seven components representing $=$ (identified $)$} & $96.28 \%$ \\
\hline \multicolumn{5}{|c|}{ Other components representing $=($ unidentified $)$} & $3.72 \%$ \\
\hline
\end{tabular}




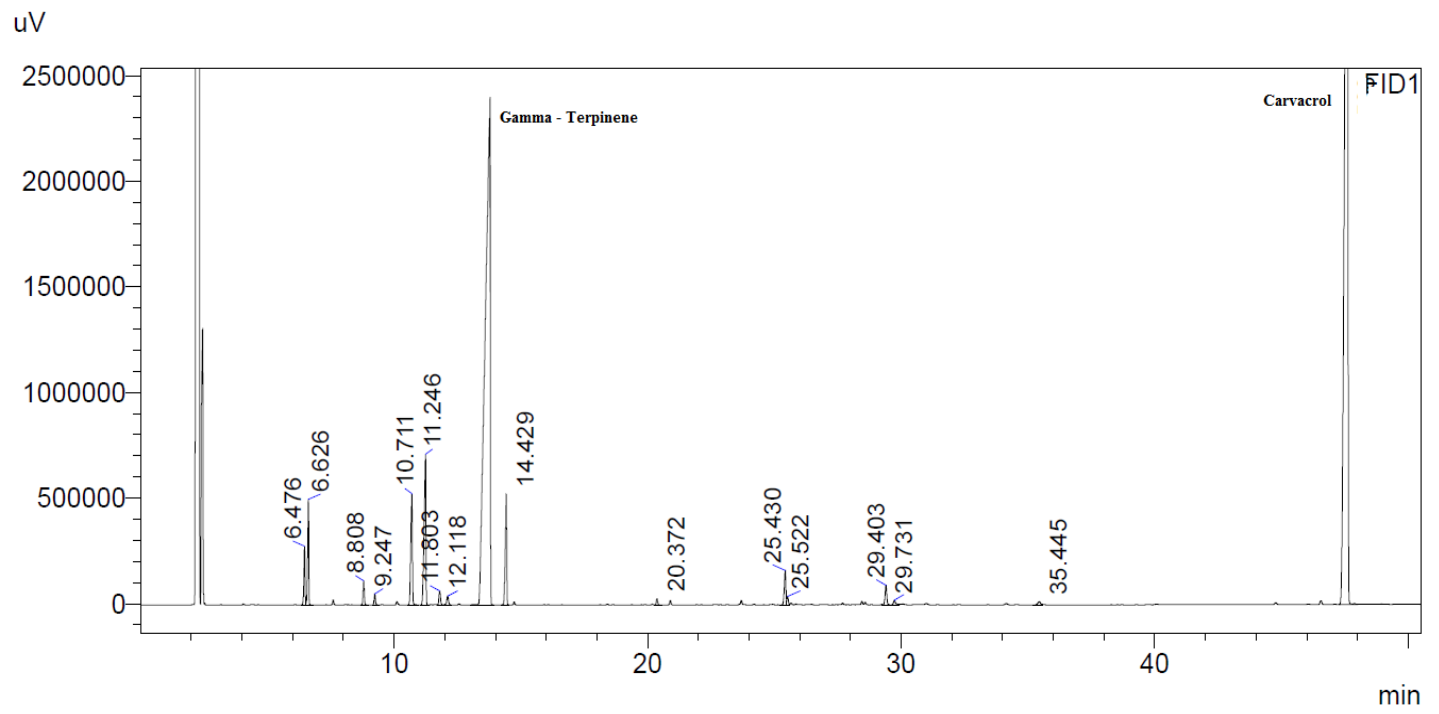

Fig.1. GC chromatogram of Satureja hortensis L. essential oil distilled from treated plants in the first season, 2014.

first season [24-26].

III. Effect of nitrogen fertilization rates, plant spacing and their interaction on total flavonoid content (mg/g D.W.)

Data presented in Tables 5 and 6 show that supplying Satureja hortensis L. plants with nitrogen fertilization treatments resulted in a marked decrease in the total flavonoids content compared to the control (unfertilized plants). The plants fertilized by N1 $(40 \mathrm{~kg} \mathrm{~N}), \mathrm{N} 2(80 \mathrm{~kg} \mathrm{~N})$ and $\mathrm{N} 3$ (120 kg N / feddan) caused a steady reduction in the total flavonoid content with mean values of $0.555,0.505$ and $0.410 \mathrm{mg} / \mathrm{g} \mathrm{DW}$ respectively, while the control plants N0 (unfertilized) resulted $0.711 \mathrm{mg} / \mathrm{g} \mathrm{D} . \mathrm{W}$., the reduction percent compared to control were $21.94,28.97$ and $42.33 \%$ in nitrogen fertilizer at N1, N2 and N3, respectively at the first cut in the first season.

Similar results were obtained in the first cut in the second season with some modification, i.e the total flavonoid contents were decreased by 47.61, 31.20 and $41.79 \%$ in N1, N2 and N3 treatments, respectively compared to unfertilized control plants [27].

The results recorded in the first cut of the two seasons in Tables 5 and 6 show that similar trend was noticed, the plants cultivated at medium spacing S2 $(30 \times 50 \mathrm{~cm})$ resulted an increase in the total flavonoid content compared to widest $\mathrm{S} 1$ $(45 \times 50 \mathrm{~cm})$ and narrowest $\mathrm{S} 3(15 \times 50 \mathrm{~cm})$, in the first season, the means were $0.557,0.542$ and 0.537 $\mathrm{mg} / \mathrm{g} \mathrm{D} . \mathrm{W}$., whereas, in the second season were $0.495,0.474$ and $0.435 \mathrm{mg} / \mathrm{g}$ D.W., respectively.

Regarding the interaction between the effect of plant spacing and nitrogen fertilizer rates on the total flavonoid content, data in Tables 5 and 6 show that the highest content $0.771 \mathrm{mg} / \mathrm{g} \mathrm{DW}$ at the first cut of the first season was produced by plant grown at the narrowest spacing $(15 \times 50 \mathrm{~cm})$ and unfertilized with nitrogen, while the lowest content $0.406 \mathrm{mg} / \mathrm{g}$ DW was recorded from plants grown at the medium spacing $(30 \times 50 \mathrm{~cm})$ and receiving the high level of nitrogen fertilizer N3 (120 kg N / feddan).

In the second season, at the second cut, the highest content of total flavonoids $0.702 \mathrm{mg} /$ g DW was produced by plants cultivated at the widest spacing $(45 \times 50 \mathrm{~cm})$ and unfertilized with nitrogen, whereas the lowest $0.291 \mathrm{mg} / \mathrm{g} \mathrm{DW}$ was determined from plants grown at widest spacing and fertilized by low level of nitrogen N1 (40 kg N / feddan).

In both seasons, at the second cut, the opposite trend was noticed in Tables 5 and 6 show that all nitrogen levels (N1, N2 and N3) increased the total flavonoids content compared to control (unfertilized plants) in both seasons.

In both seasons, at the second cut, planting at the medium spacing $(30 \times 50 \mathrm{~cm})$ gave the 


\begin{tabular}{|c|c|c|c|c|c|}
\hline \multirow{3}{*}{ Plant Spacing(S) } & \multicolumn{4}{|c|}{ Nitrogen fertilization(N) } & \multirow[t]{2}{*}{ Mean } \\
\hline & No & N1 & $\mathbf{N} 2$ & N3 & \\
\hline & \multicolumn{4}{|c|}{ First cut } & \\
\hline S1 & 0.675 & 0.590 & 0.486 & 0.416 & 0.542 \\
\hline $\mathbf{S 2}$ & 0.687 & 0.578 & 0.556 & 0.406 & 0.557 \\
\hline S3 & 0.771 & 0.496 & 0.472 & 0.408 & 0.537 \\
\hline \multirow[t]{2}{*}{ Mean } & 0.711 & 0.555 & 0.505 & 0.410 & \\
\hline & \multicolumn{4}{|c|}{ Second cut } & \\
\hline S1 & 0.372 & 0.265 & 0.612 & 0.712 & 0.490 \\
\hline S2 & 0.645 & 0.726 & 0.800 & 0.777 & 0.737 \\
\hline $\mathbf{S 3}$ & 0.472 & 0.582 & 0.733 & 0.689 & 0.619 \\
\hline Mean & 0.496 & 0.524 & 0.715 & 0.726 & \\
\hline \multicolumn{6}{|c|}{ N. fertilization: $\mathrm{N} 0=0.0, \mathrm{~N} 1=20, \mathrm{~N} 2=40$ and $\mathrm{N} 3=80 \mathrm{Kg} \mathrm{N} /$ feddan } \\
\hline \multicolumn{6}{|c|}{ Plant spacing: $\mathrm{S} 1=45 \mathrm{~cm}, \mathrm{~S} 2=30 \mathrm{~cm}$ and $\mathrm{S} 3=15 \mathrm{~cm}$} \\
\hline
\end{tabular}

\begin{tabular}{|c|c|c|c|c|c|}
\hline \multirow{2}{*}{ Plant Spacing (S) } & \multicolumn{4}{|c|}{ Nitrogen fertilization(N) } & \multirow[t]{2}{*}{ Mean } \\
\hline & No & N1 & $\begin{array}{c}\text { N2 } \\
\text { First ct }\end{array}$ & N3 & \\
\hline S1 & 0.702 & 0.291 & 0.420 & 0.483 & 0.474 \\
\hline S2 & 0.651 & 0.412 & 0.555 & 0.360 & 0.495 \\
\hline S3 & 0.656 & 0.351 & 0.407 & 0.327 & 0.435 \\
\hline Mean & 0.670 & 0.351 & $\begin{array}{r}0.461 \\
\text { Second }\end{array}$ & 0.390 & \\
\hline S1 & 0.299 & 0.202 & 0.310 & 0.489 & 0.325 \\
\hline S2 & 0.324 & 0.324 & 0.304 & 0.486 & 0.360 \\
\hline S3 & 0.321 & 0.366 & 0.319 & 0.277 & 0.321 \\
\hline Mean & 0.315 & 0.297 & 0.311 & 0.417 & \\
\hline
\end{tabular}

highest content, with mean values of 0.737 and $0.360 \mathrm{mg} / \mathrm{g} \mathrm{D}$.W. in the first and second seasons, respectively, whereas the widest and narrowest spacings gave the lowest content, similar results recorded at the first cut in both seasons.

Concerning the interaction between the effect of nitrogen levels and plant spacings on the total flavonoid contents, data in Tables 5 and 6 show that the highest total flavonoid content $0.800 \mathrm{mg} /$ g D.W. produced by plants receiving the N2 level $(80 \mathrm{~kg} \mathrm{~N} /$ feddan $)$ and planted at S2 $(30 \times 50 \mathrm{~cm})$ spacing. On the other hand, the lowest content $0.265 \mathrm{mg} / \mathrm{g}$ D.W. resulted from plants fertilized by low level of nitrogen N1 (40 kg N / feddan) and transplanted at the widest spacing S1 $(45 \times 50 \mathrm{~cm})$ at the second cut in the first season. Moreover, the highest content of total flavonoids $0.489 \mathrm{mg}$ /g DW was produced from plants receiving the high level of nitrogen N3 (120 kg N / feddan) and planted at the widest spacing $(45 \times 50 \mathrm{~cm})$, while the lowest content $0.202 \mathrm{mg} / \mathrm{g}$ DW was recorded from plants fertilized with $\mathrm{N} 1$ level and cultivated at the widest spacing $\mathrm{S} 1(45 \times 50 \mathrm{~cm})$ in the second season.

In general, the plants fertilized by the different nitrogen levels (N1, N2 and N3) resulted gradual steady increase in the total flavonoid content at both cuts of the first and second seasons. The favorable effect of nitrogen fertilization on the total flavonoid content in summer savory plant may be explained by increase in the $\mathrm{N}$ uptake by the plants of the nutrients involved in the synthesis and accumulate of the different secondary products such as total flavonoids [22,26,28,29]. 


\section{Conclusion}

Improvement of essential oil production of summer savory, Satureja hortensis L. plant was achieved by increasing the amount of nitrogen fertilizer to the rates of 400 and $600 \mathrm{~kg} /$ feddan of ammonium sulfate fertilizer $(20.5 \% \mathrm{~N})$ under Egyptian weather conditions. The maximum production of flavonoids was that of plants grown without application of nitrogen fertilization in June harvesting. On the other hand, the plant of August harvesting had improved synthesis and accumulation of flavonoids with higher $\mathrm{N}$ fertilization values. The optimum production of essential oil and flavonoid content was recorded with the heavy planting (30 or $15 \mathrm{~cm}$ spacing). The results of study may help the Egyptian growers to increase essential oil.

\section{$\underline{\text { References }}$}

1. Momtaz, S. and Abdollahi, M., An update on pharmacology of Satureja Species: From antioxidant, antimicrobial, Antidiabetes and antihyperlipidemic to reproductive stimulation. Int $J$ Pharmacol. 6, 454-61 (2010).

2. Robert, M.D. and Francis, H.W., Plant physiology. PWS publishers, A division of Wadsworth, Inc., Boston, USA (1986).

3. Babalar, M., Mohtashami, S., Tabrizi, L. and Roshan, V., The effect of different levels of ammonium sulfate on photosynthesis pigments, essential oil content, yield and component of improved summer Savory (Satureja hortensis L. cv. Saturn). Iranian Journal of Horticultural Science. 47 (3), 481- 490. 30 (2016).

4. Hassanzadeh, R., Jahan, M., Hosseini, N. M., Nezami, A. and Moghaddam, P. R., Deficit irrigation and macro and micro fertilizers effects on morphophysiological traits of summer annual savory (Satureja hortensis L.). Iranian Journal of Field Crop Science.46( 2), Pe277-Pe286. 28 (2015).

5. Jalili, F., The effect of N, P and micronutrients on yield and essential oil of Satureja hortensis L. Advances in Environmental Biology. 9 (3), 860865.25 (2015).

6. Sabry, R., Salama, A. and Sharaf-Eldin, M., Herbage growth, yield and oil content of Marrubium vulgare grown in Egypt as affected by plant spacing and nitrogen fertilization. Zeitschrift fur Arznei- \& Gewurzplanzen. 17 (4), 164-168. 27 (2012).

7. Akbarinia, A., Response of Satureja sahendica Bormn. to nitrogen and plant density. Iranian Journal of Medicinal and Aromatic Plants. 29 (2),261-267, En268. 12 (2013).

8. Gopichand, Meena, R. L., Manu Nag, Pathania, V. L., Kaul, V. K., Bikram Singh, Singh, R. D. and Ahuja, P. S., Effect of organic manure and plant spacing on biomass and quality of Mentha piperita L. in Himalaya in India. Journal of Essential Oil Research. 25 (4), 354-357. 11(2013).

9. Raina, N. S., Rafiq, M., Sood, K. K., Bali, A. S., Gupta, S. K. and Sehgal, S., Growth and yield of Ocimum sanctum in response to integrated nutrient management and plant spacing. Indian Journal of Agronomy. 58 (1), 129-132 (2013).

10. Yousefzadeh, S. and Sabaghnia, N., Growth characters and yield of dragonhead in relation to $\mathrm{FE}_{2} \mathrm{O}_{3}$ nano-scale fertilizer and sowing density. Agriculture and Forestry. 62(2), 59-70. 40 (2016).

11. Zahedifar, M. and Najafian, S. H., Combined effect of soil applied iron and sulfur fertilisers on monoterpene content and antioxidant activity of Satureja hortensis L. extract. Pertanika Journal of Tropical Agricultural Science 38 (3), 361-374 (2015).

12. El-Gohary, A. E., El-Gendy, A. G., Hendawy, S. F., El-Sherbeny, S. E., Hussein, M. S. and Geneva, M., Herbage yield, essential oil content and composition of summer savory (Satureja hortensis L.) as affected by sowing date and foliar nutrition. Genetics and Plant Physiology 5 (2), 170-178. 14 (2015).

13.Anoosh Eghdami and Fatemeh Sadeghi, Determination of total phenolic and flavonoids contents in methanolic and aqueous extract of Achillea Millefolium. Org. Chem. J.2, 81-84 (2010).

14. Milan S. Stanković, Total phenolic content, flavonoid concentration and antioxidant activity of Marrubium peregrinum L. extracts. Kragujevac J. Sci. 33, 63-72 (2011).

15. Ovais Ullah Shirazi, Muhammad Muzaffar Ali Khan Khattak, Nor Azwani Mohd Shukri and Mohd Nur Nasyriq. A., Determination of total phenolic, 
flavonoid content and free radical scavenging activities of common herbs and spices. Journal of Pharmacognosy and Phytochemistry .3 (3), 104108 (2014).

16. Guenther, E., The Essential Oils. Vol (1): D'Van Nostrand Co., New York, pp: 236 (1961).

17. Tatjana Mihajilov-Krstev, Dragan Radnović, Dušanka Kitić3, Bojan Zlatković1,Mihailo Ristić and Suzana Branković,Chemical composition and antimicrobial activity of Satureja hortensis L. essential oil. Central European Journal of Biology. 4 (3) , 411-416 (2009).

18. Sandra Gouveia and Paula C. Castilho, Antioxidant potential of Artemisia argentea L'Hér alcoholic extract and its relation with the phenolic composition. Food Research International 44, 1620-1631 (2011).

19. Little, T. M. and Hills, F. J., Agricultural Experimentation - Design and Analysis. John Wiley and Sons, Inc., pp. 53-60 (1978).

20. El-Sayed, A. A., Physiological study on geranium plants (Pelargonium graveolens L.) as affected by GA and CCC. Ph. D. Thesis, Fac. Agric. Cairo Univ., Egypt (1979).

21. Heikal, A.A.M, Effect of organic and biofertilization on the growth, production and composition of thyme (Thymus vulgares L.) plants. M.Sc. Thesis, Fac. Agric., Cairo Univ., Egypt. pp86 (2005).

22. El-Sayed, A. A., Mahassen M. A. Sidky, Mansour, H. A. and Maie M. A. Mohsen, Effect of organic fertilizer and Egyptian rock phosphate on the growth, chemical composition and oil production of tarragon (Artemisia dracunculus L.). Journal of Productivity and Development. 14 (1), 87-110 (2009).

23. Ali, R. M. M., Improving growth and active constituents using some natural stimulants under different climate conditions in coriander Coriandrum sativum L. plants. Ph. D. Thesis, Fac. Agric. Mansoura University., Egypt. pp77 (2016).

24. Kandil, M. A. M., Khatab, M. E., Ahmed, S. S. and Schnug, E., Herbal and essential oil yield of genovese basil (Ocimum basilicum L.) grown with mineral and organic fertilizer sources in Egypt. Journal fur Kulturpflazen, 61(12), 443-449(2009).

25. Runyoro, D., Ngassapa, O., Vagionas, K., Aligiannis, N., Graikou, K. and Chinou, I., Chemical composition and antimicrobial activity of the essential oils of four Ocimum species growing in Tanzania. Food Chemistry, 119 (1), 311-316(2010).

26. El-Zaiat, R. A. M., Herb and essential oil production of three Ocimum species as affected by chicken manure and humic acid treatments. Ph. D. Thesis, Fac. Agric. Cairo Univ., Egypt (2015).

27. Roslon, W., Osinska, E., Baczek, K. and Weglarz, $Z$., The influence of organic-mineral fertilizers on yield and raw materials quality of chosen plants of the Lamiaceae family from organic cultivation. Acta Scientiarum Polonorum - Hortorum Cultus. 10 (1),147-158. 21 (2011).

28. Joy, P. P., Thomas, J., Mathew, S. and Skaria, B. P., Effect of spacing and manuring on growth, yield and nutrient content of Alpinia galangal L. Willd. J. of Spices and Aromatic Crops, 11 (1), 22-25. (C.f. Hort. Abst., 73, 5934) (2002).

29. Anyin Chen, Wenjun Xiang, Dan Liu, Changlu Liu and Li Yang, Determination of total flavonoids and its antioxidant ability in Houttuynia cordata. Journal of Materials Science and Chemical Engineering 4, 131-136(2016).

(Received 5/7/2017; accepted 13/8/2017) 
تأثثر التسميد النيتروجيني و مسافات الزراعة على محتوى الزيت العطرى و الفلافونيدات

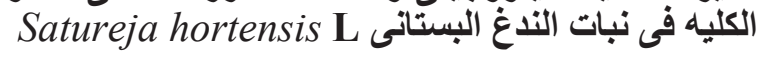

\author{
أحمد سلامه الليثى' ، صفية حمدى محمـود' ، محد الاسوقـى خطابّ، صـلاح سيد أحمد و أحمد عبد

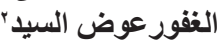

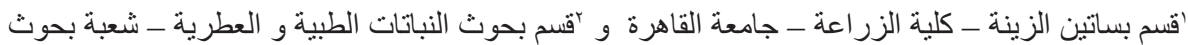

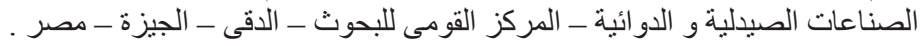

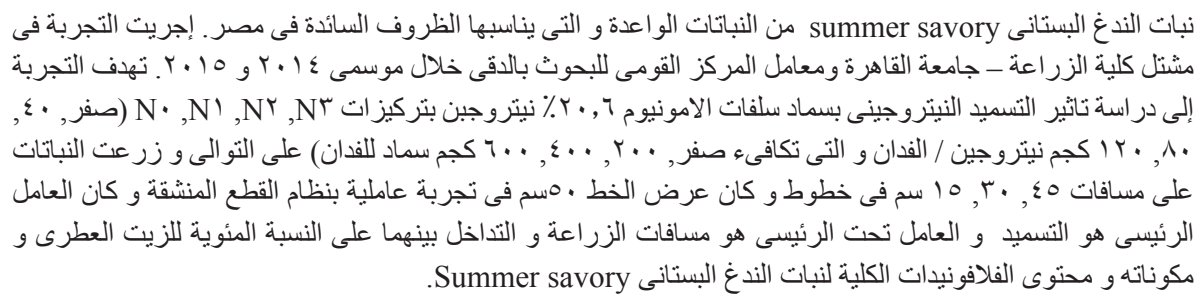

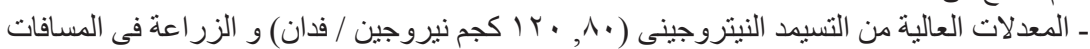

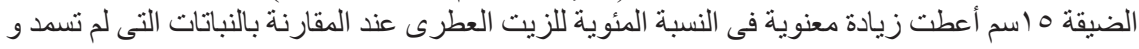
التى زر عت على مسافات و اسعة 0 ؛سم.

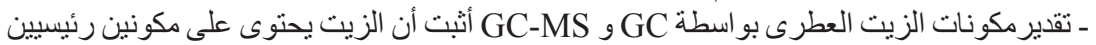

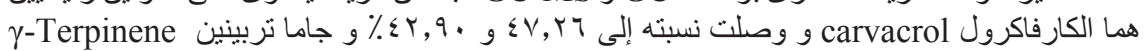

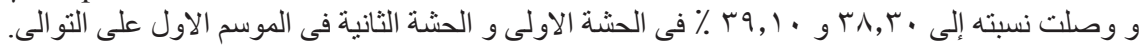

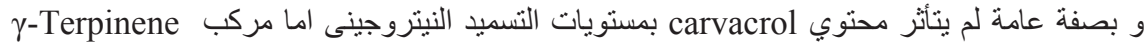

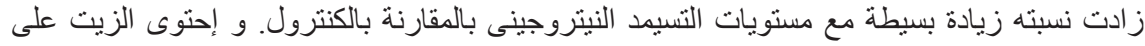

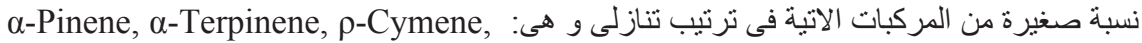
Terpinolene $\alpha$-Thujene المركبات.

ـ الفلافونيدات الكلية حدث لها نقص مع مستويات التسميد النيتروجينى المختلفة فى الحشة الاولى الهي

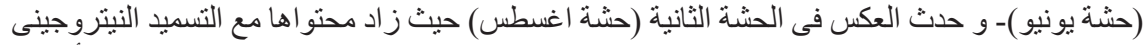

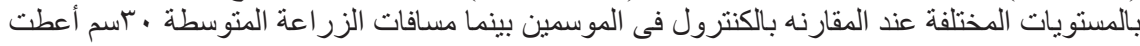

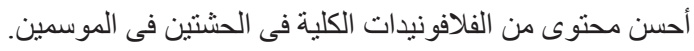

